\title{
Someone Is Always Already There In Front Of You Even Though You May Not Like It
}

\author{
Frieder Nake \\ University of Bremen, Mathematik / \\ Informatik \\ nake@uni-bremen.de
}

\begin{abstract}
In many ways, humans in modern societies seem to be occupied to a considerable amount by a longing to establish whatever they do as if it were the first time any human has ever done it. The arts are full of this myth of originality and firstness. However, at closer inspection, there often appear events or activities by someone else that were at least foreshadowing what later appeared as totally new and the first time. The article takes up a few cases of this kind related to digital art.
\end{abstract}

\section{KEYWORDS}

Computer Art; Conceptual Art; Master Piece; Infinite Image; Experiment.

\section{ARTICLE INFO}

Received: 26 November 2018

Accepted: 30 November 2018

Published: 18 December 2018

https://dx.doi.org/10.7559/citarj.v10i3.569

\section{1 | INTRODUCTION}

The reader of these lines will in many cases agree with what the article's heading says when he thinks, or she, of a busy street in the city center during an ordinary day of the week. She will, however, tend to disagree at least a bit if she imagines herself on a late Sunday night, at 11 p.m., when this November night is cool and rainy and a wind is coming up howling along the streets. Everybody has apparently already gone home, where they may be sitting in convenient chairs, surrounded by cozy lights and cracking sounds coming from the fireplace, the taste of a good cognac on their lips. But she is walking, yes indeed, she's walking down the street with nobody in front of her. But she would want someone to be precisely there, now in the rainy November night, in front of her.

Now, don't be afraid, dear reader, ramblings of this kind will not be our subject matter. We will not be concerned here with the spatial more or less linear sequence of people in city streets. Our concept of 


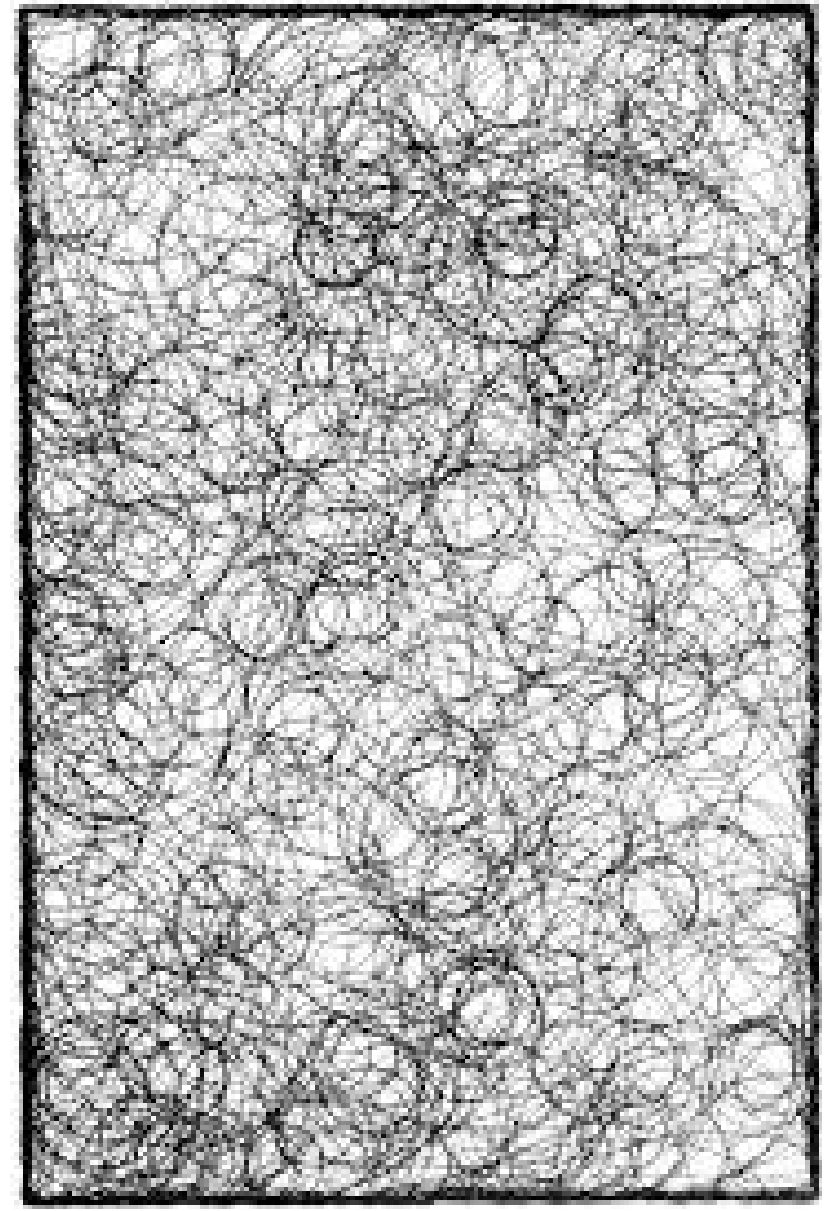

Figure 1 | Georg Nees, Gewölle. Experiment in texture. 1965.

"in front of" will be more of temporal kind, if not metaphorical. We will take up a few characteristics of digital art and expose them to questions like "How new is this really? What exactly of this artistic expression is as outstanding as we often hear digital art being acclaimed for?"

In trying to do so, I am not led by a claim that maintains assertions like this: "Oh no, nothing in computer art is really new, it's just a continuation of what we've always done, the only difference is that now you do the same as before, only now you do it by use of computers." In our selection of a few characteristic cases, we see continuation of the old in new form. By those examples we want to identify the absolutely new in the historic break that happened in the mid-1960s when thinking the image became more important than making it. The reader should not consider any of those cases as final, irrevocable, unquestionable, or even only true. You will, I'm sure, read them a bit as off the tracks that you are so familiar with. You should, I plead, read what I write as what I write and nothing more.

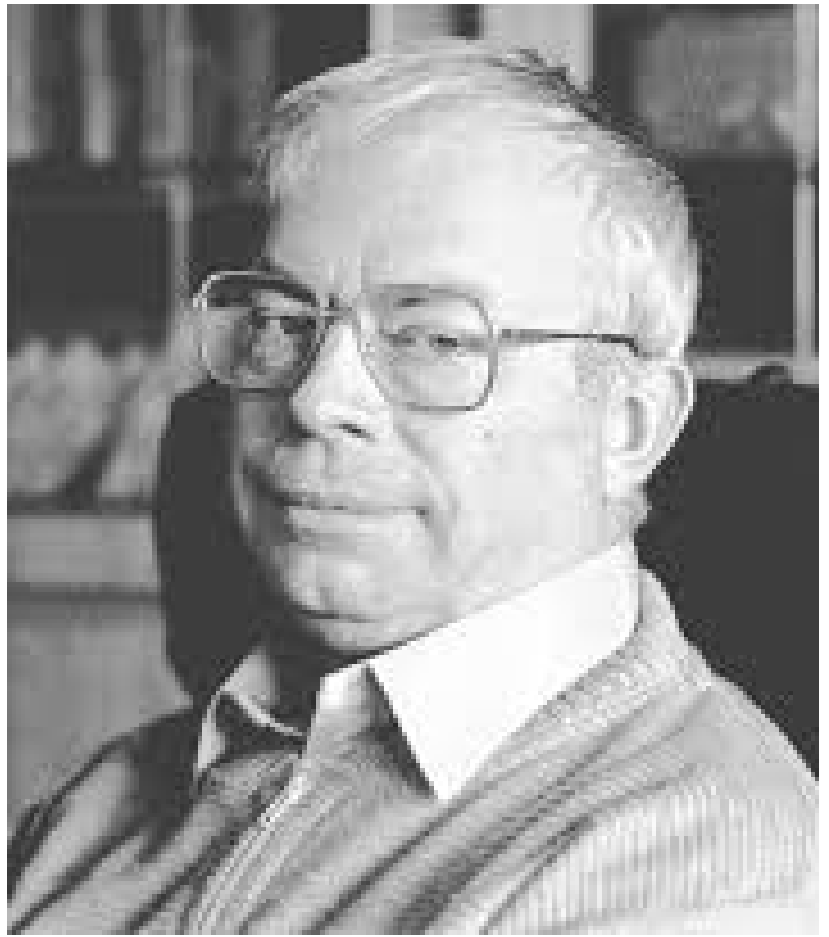

Figure 2 | Georg Nees (1926-2016).

\section{2 | AN ARTIST AND A MATHEMATICIAN}

The story has often been told of the opening of the first exhibition of computer art, which was then called "generative computer graphics". I want to bring it back to your attention anyway. Accidentally, the title of the exhibition may have been simply "computer graphics" (Computer-Grafik). Nobody seems to remember precisely. The artist, who for the first time showed his works as a collection of smallsized programmed drawings, was a mathematician. A fact that I would not consider to be of extra relevance. But soon, when first reports appeared in the press, use was made of the term "only" in connection with the fact a mathematician was the creator. Like a mantra, this was supposed to tell the readers: "Don't take this too seriously, it is only mathematicians or engineers who are doing this kind of thing. Not artists."

The artist responsible for the exhibited works was Georg Nees (Figure 2). He was working for the research section of the Computing Center of the Siemens Company in Erlangen, Germany. The exhibition was put up on 5 February 1965, in rooms of the Studiengalerie of the Technische Hochschule in Stuttgart.

Max Bense, the radically rational philosopher, author of books on the new information aesthetics, read his text Projekte generativer Ästhetik, that later 


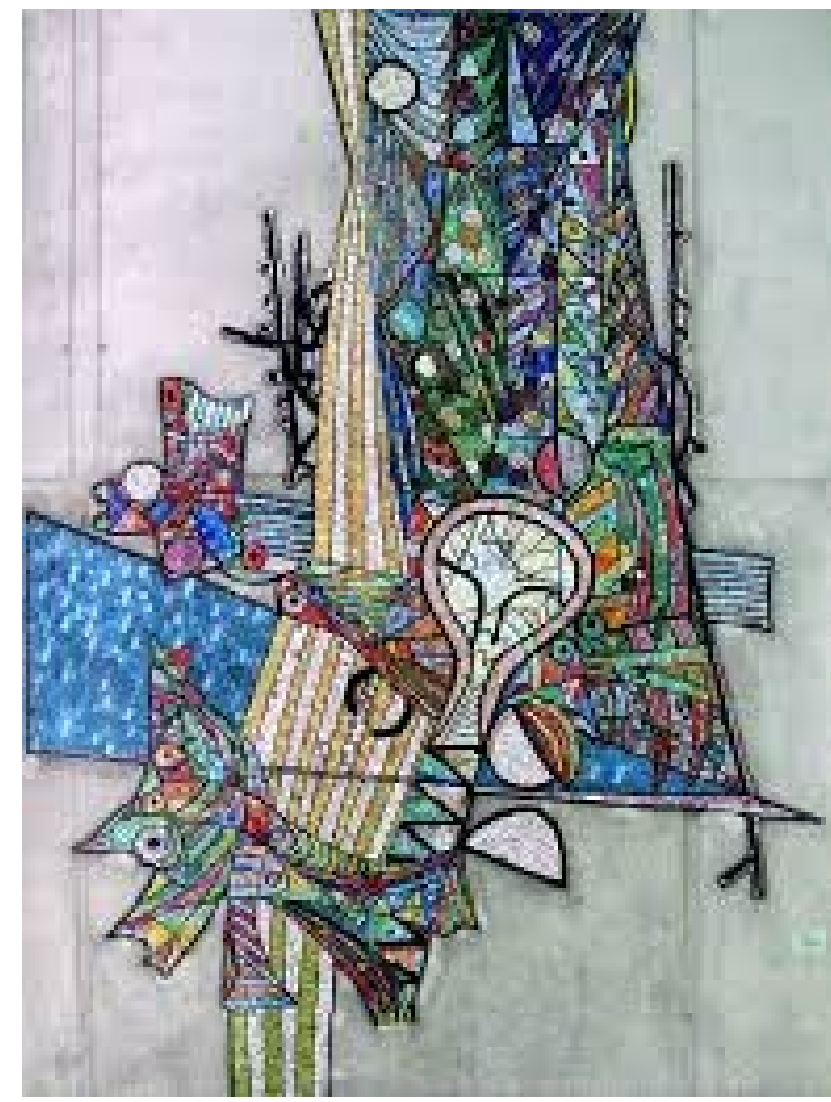

Figure 3 | Heinz Trökes, Glass mosaic for a school in Hamburg. 1957.

appeared in an English translation. Up to now, aesthetics used to be critical and analytic. Bense turned it around by initiating a theoretical background for synthetic and generative aesthetics, from which new artistic practice should emerge.

After Bense's short presentation, Nees told the audience how it is possible to force a computer after all, a machine made to calculate and not to draw - into exactly this: into drawing. Not enough, those automatic drawings (Figure 1) would also possess aesthetic, maybe even artistic, qualities.

Part of the audience was a group of local artists, some of them well-known in a German context. One of them, Heinz Trökes (Figures 3 and 4), challenged the mathema-tician: "That sounds quite interesting, young man. But tell me one thing: Can you make your machine paint (or draw) like I do it?" We do not know what kind of answer Trökes expected. Allowing myself to speculate a bit, he probably wanted the technical thinker to surrender and say, "of course not, never".

However, Nees thought for a moment about the proper reaction, and then clearly and crisply came

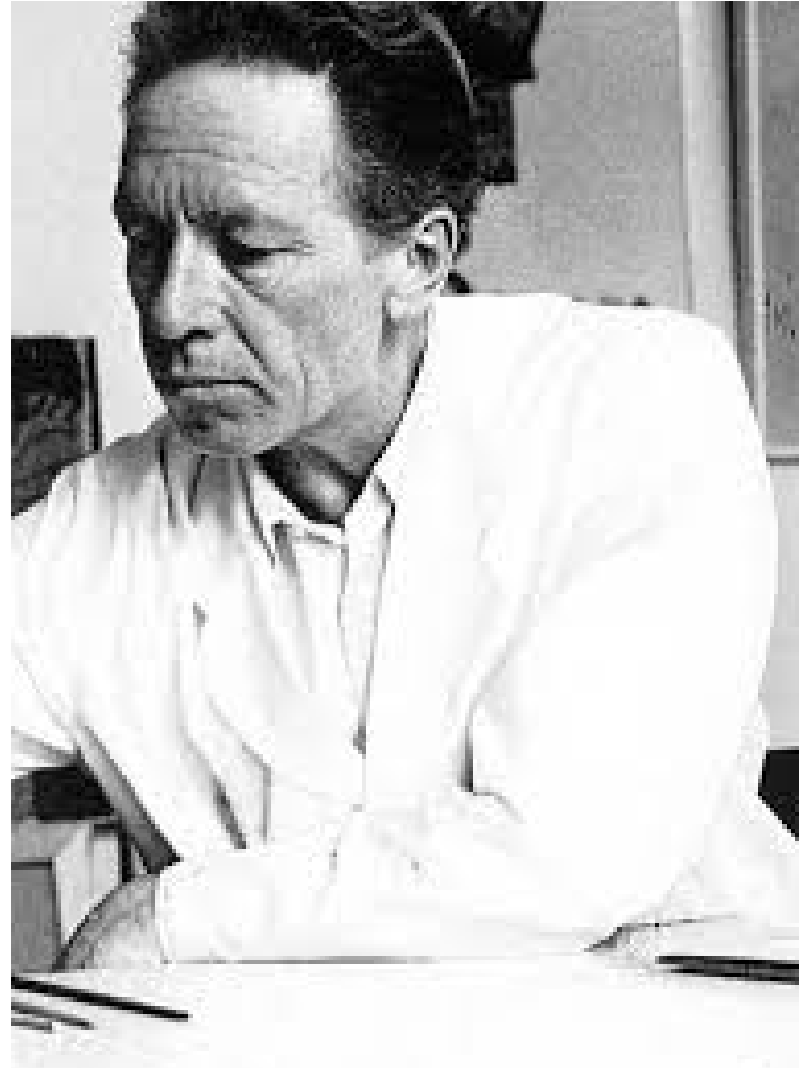

Figure 4 | Heinz Trökes (1913-1997).

out with: "Oh yes, of course I can - if you tell me how you do it yourself!" Fantastic! Daring! Ingenious! Nees may not have realized himself that he had put into those few words the greatest answer that all speculations about possible and imagined achievements of Artificial Intelligence (A.I.) ever deserve. Since A.I. is human-made, artificial, it can be done only if taken away from its natural origin and experience, and that can be done only by explicit description. We can always talk about a phenomenon. But if we want to rebuild the phenomenon, we must first describe it. If it is to be simulated by computers, it must even be described in terms of computability.

The anecdote ends with the artists furiously leaving the place, shouting aggressive utterings about the insulting answer that they cannot, and will never, tolerate, which forces them to leave the place.

Nothing of this kind is known about an opening at the Howard Wise Gallery in New Yorktwo months later, on 6 April 1965, of the exhibition Computergenerated Pictures. A. Michael Noll and Béla Julesz were showing. The Germans and the Americans did not know of each other. There is always already someone in front of you... 


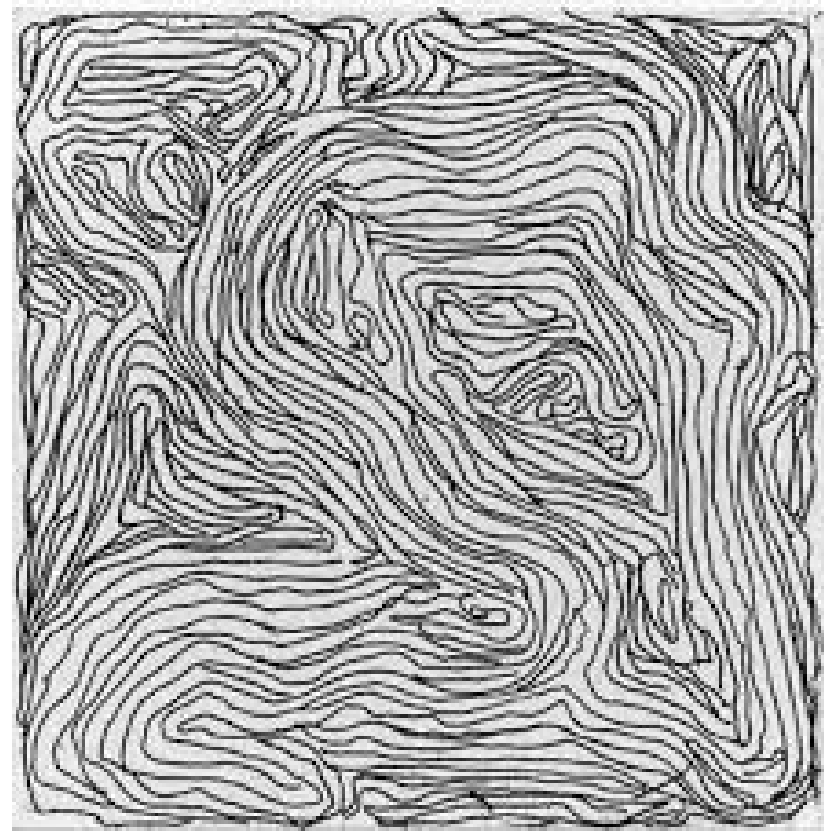

Figure 5 | Sol LeWitt, Small etching / black and white no. 7, 1999.

\section{3 | CONCEPTUAL ART AND MACHINES}

"Vertical lines, not straight, not touching, uniformly dispersed with maximum density; covering the entire surface of the paper." This is a typical description, short, clear, precise. Really? Apparently precise enough for its author, conceptual and minimal artist Sol LeWitt (Figure 6), to pass his "Instruction" on to

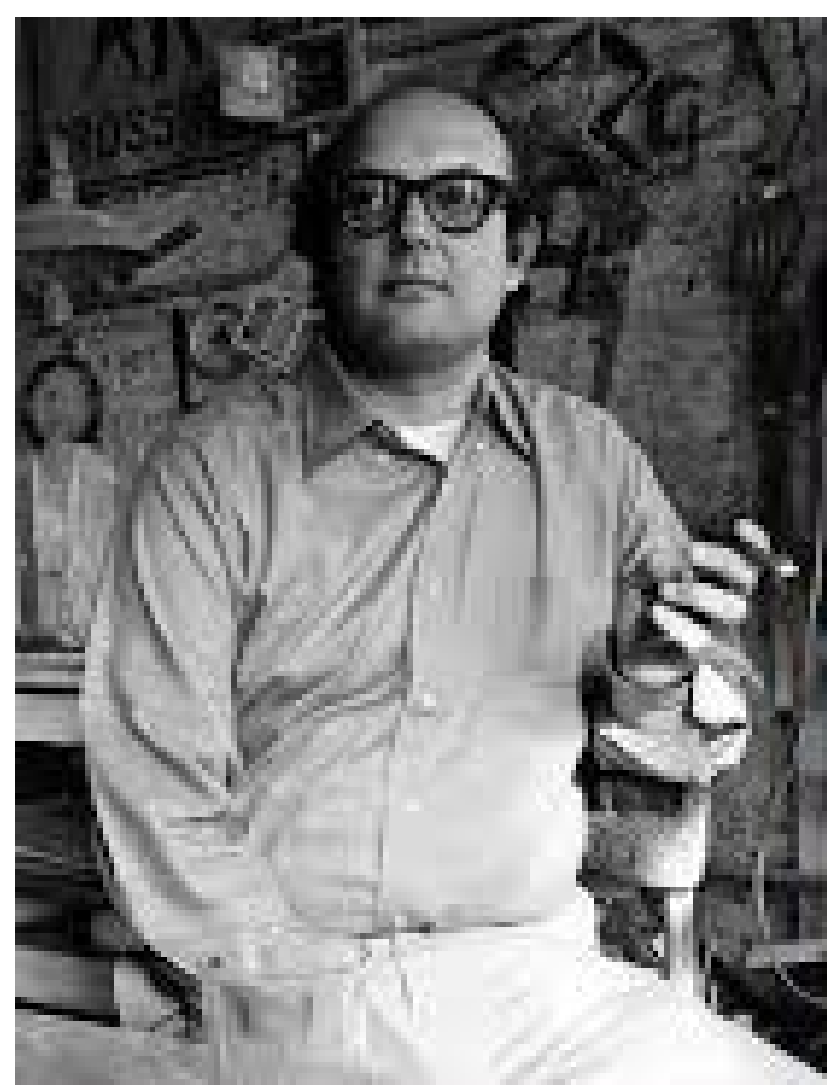

Figure 6 | Sol LeWitt (1928-2007). students to carry it out. LeWitt has written, recorded, and published dozens of similarly formulated instructions, several of which have been carried out at different locations, under differing conditions, and, most importantly, by different groups of individuals. The artist did not do more than express in his style the idea. Other were doing the manual work (Figure 7), which implied, of course, a lot of interpretation. What is "uniformly dispersed", "maximum density"? What is a vertical line that is not straight?

Any such question will find its more or less convincing answer by anyone who will, in acting out the instruction, nevertheless do almost any detail different than her neighbors.

How complex can such an instruction become, before the human interpreter-maker doubts whether she is still following LeWitt's instruction, or her own ideas? She is supposed to stay with the rules, but the degree of openness of the rule's formulation may cause her to doubt (cf. Figure 5)

The instruction is not a program. The interpreter is not a machinic evaluator (processor). Unless the machine is permitted to inject pseudo-random decisions (by random number generation), its "interpretation" is the limiting case of interpretation,

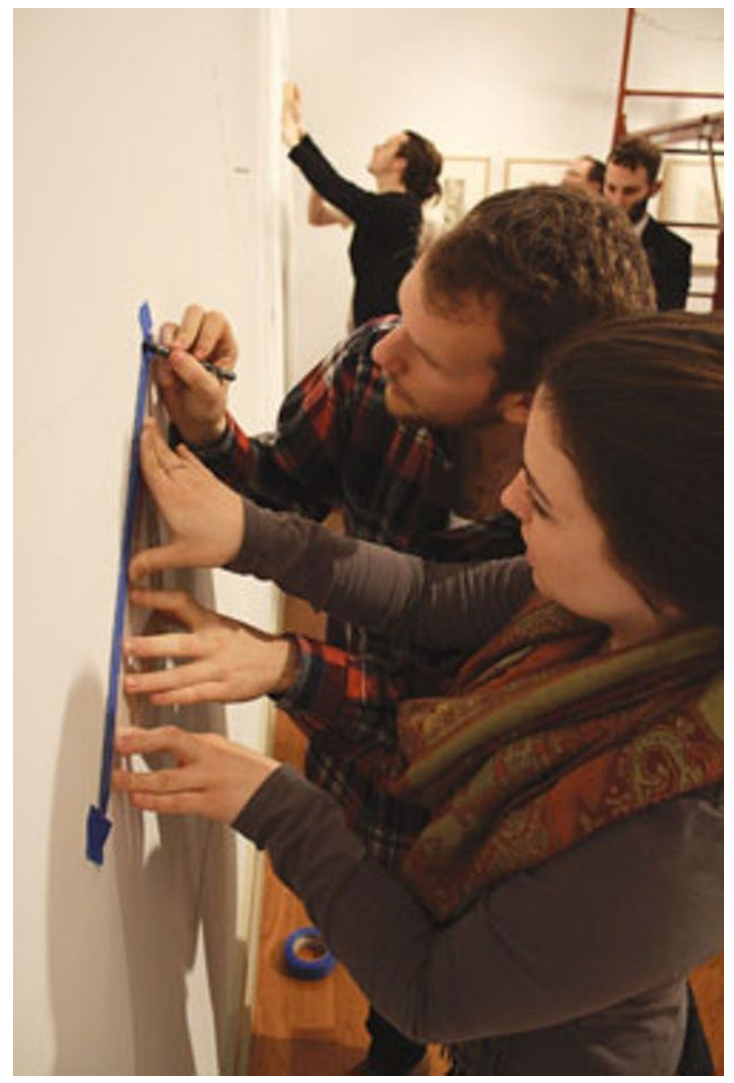

Figure 7 | Students carrying out a concept of Sol LeWitt's. 


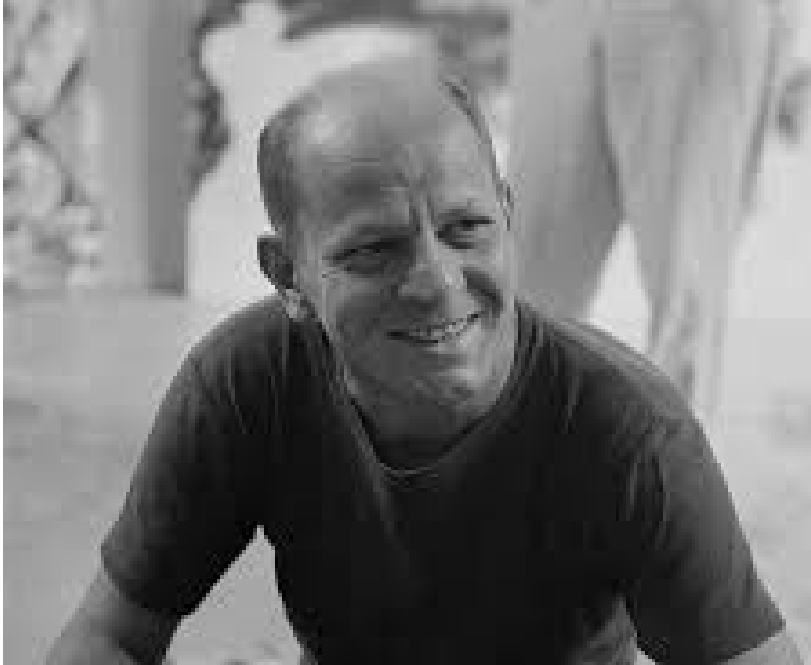

Figure 8 | Jackson Pollock (1912-1956.

and that is determination. Determining the one and only possible interpretation, or to give up (because there does not seem to be a uniquely defined interpretation) - this kind of pseudo-interpretation we call "determination". There is no free choice in a correct algorithm and program; there is only determination of the uniquely determined reading of the instruction.

Where the computer program is carried out by the processor, LeWitt had people carry out his instruction. Man as a machine (cf. de La Mettrie 1912), finally realized?

Sol LeWitt is known for his writings as much as for his works. The most famous of his Paragraphs on Conceptual Art is "The idea becomes a machine that makes the art" (LeWitt, 1967). The machine, in this case, was quicker than the thought. I would have felt better, had I once written a letter to LeWitt, say in 1969 or so, whenever it may have been that I became aware of his "paragraphs". The letter should have contained this:

\section{Dear Sol LeWitt:}

you do not know me, how and why should you? Neither do I know you other than through your work and writing, your "Paragraphs", in particular. The idea becomes a machine that makes the art, you say. That's beautiful because it expresses in a radical formulation a lot of what is going on in current stormy developments that you and

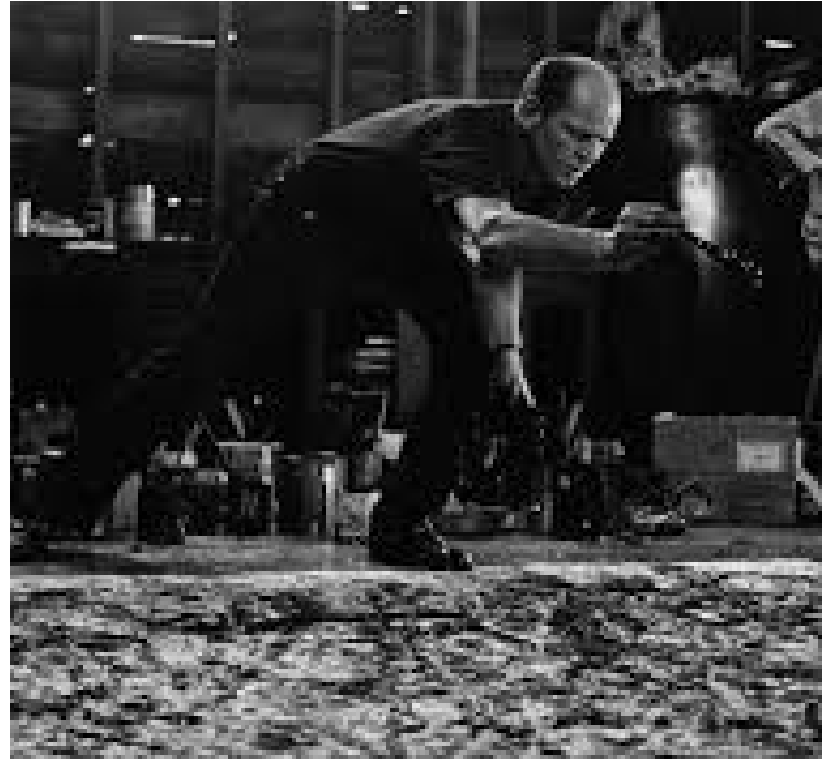

Figure 9 | Pollock in action, painting from a distance.

- forgive me - I also love so much. However, I should submit to you the fact that some years before you formulated your wonderful principle of idea and machine, I had already done it. I tend to believe there is always already someone in front of us. Please, take this as nothing more but a faint voice from the other side of the ocean.

Yours ...

Sol LeWitt's paragraph lets us think in a different way about what we do when we develop algorithms and have them actually implemented in form of a running program.

\section{4 | JACKSON POLLOCK AND DISTANCE}

He desperately wanted to become the most famous painter of the USA, and he succeeded in the end, even though he did not find time enough to really be happy about the invention of drip painting, and celebrate it from 1947 to 1950 , before a few years later he crashed his car under the influence of alcohol. He had invented mechanisms of painting that did not require any carefully designed structure and composition. They were rather techniques of applying paints from a distance, hardly touching the canvas with a brush, but throwing the paint, dripping and splashing it in outbursts of his emotion vis-à-vis the canvas. A struggle of taking painting as an action of the entire body against the empty canvas. 


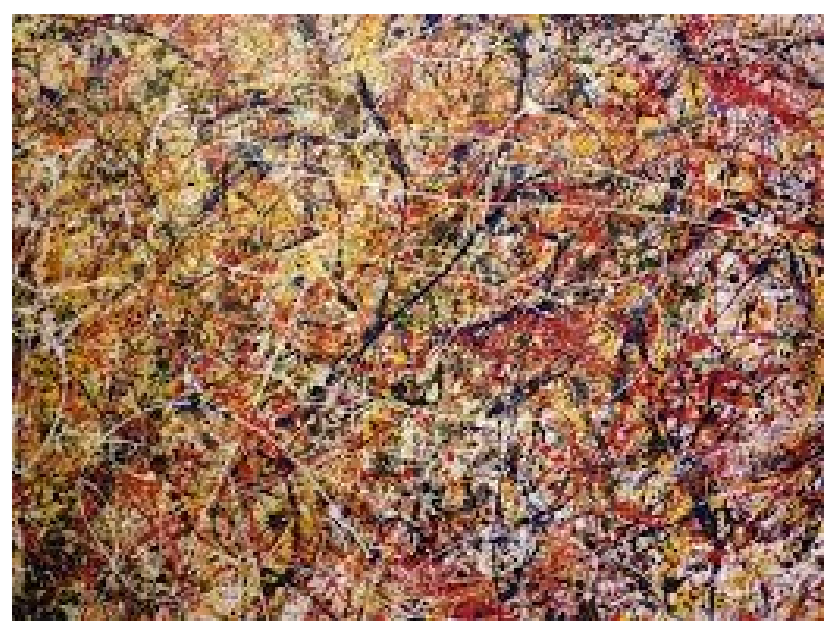

Figure 10 | Jackson Pollock, Drip Painting, 1951.

Whatever is to be said about Pollock's (Figure 8) abstract expressionist style, his success came with his retreat from the close sensual touch that painters may experience when caressing the canvas in their attempts to force it to express what they want the canvas to show.

The distance of the artist from the canvas (Figure 9) or other carrier of his work is, of course, a feature of any algorithmic art. The artist engaged in thinking the image - perhaps as heavily as Pollock did when he was in action - is, in a certain sense, continuing Pollock's invention and, indeed, taking the thinking of the image to mature (Figure 10).

\section{5 | JOSEF ALBERS AND THE EXPERIMENTAL LABORATORY}

When teaching at the Bauhaus, and later at Black

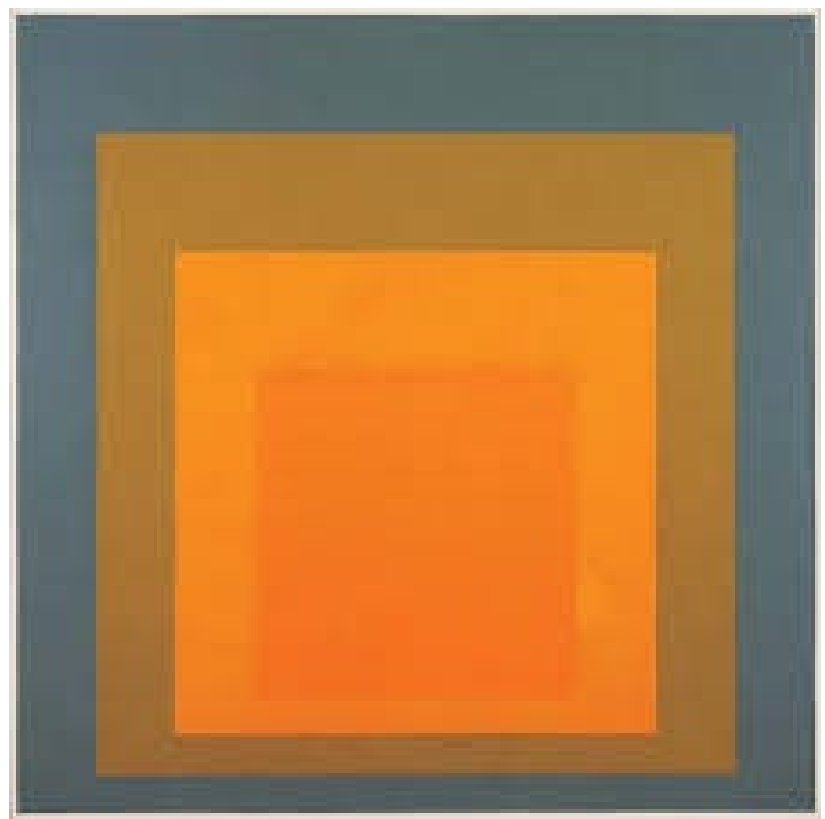

Figure 11 | Josef Albers, Homage to the square: Festive, 1967 (photo R.H. Hensleigh).
Mountain College, Josef Albers (Figure 12) drew a sharp line between his teaching and art. When you go to college, you are a student, not an artist. Whether your work will later be recognized as "art" is a question whose answer may find some justification in your early active years, but it will there certainly not find its very reason. Of his own work he thought as experiments - experiments mainly in color. He wrote of it as "visual research".

In a late interview for the journal Leonardo, Albers shows himself surprised: "I come to a surprising conclusion, namely that I did not teach arts as such, but philosophy and psychology of art" (Holloway \& Well, 1970, p. 459). Paraphrasing this: Does an artist, when teaching, whose artistic work is largely based on programming, not teach arts as such, but algorithmics and mathematics?

From 1950 to 1976, Albers' painting was reduced to variations in color only, using one and the same formal structure: a nested set of four squares, always arranged in the same relative locations and proportions (Figure 11). The only tiny variation he allowed himself was to drop one of the inner three squares so that there occasionally appear three more structures of three squares (instead of four) each. We may think of those 26 years of Albers' creative life (almost one third of it) as turning his studio into a laboratory for visual research. That became the term he used for his art.

His research topic was the "Interaction of color".

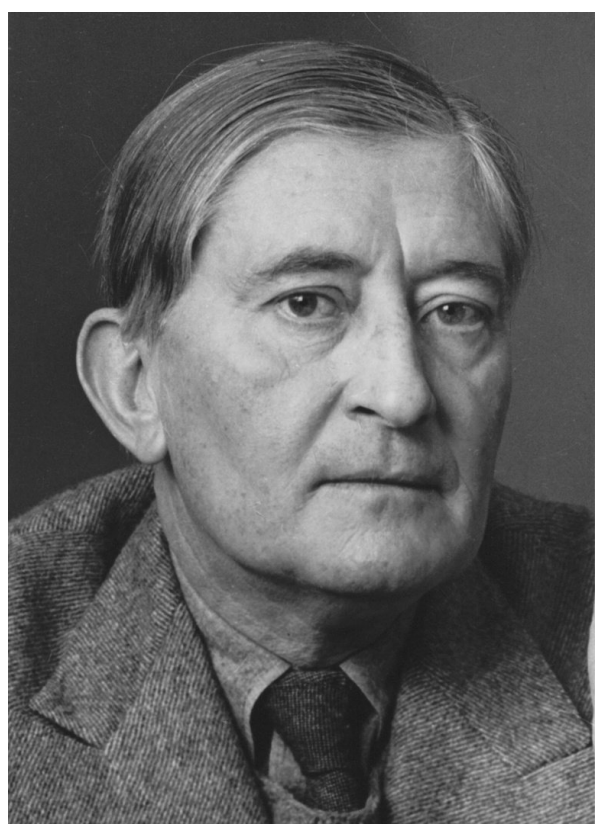

Figure 12 | Josef Albers (1888-1976). 


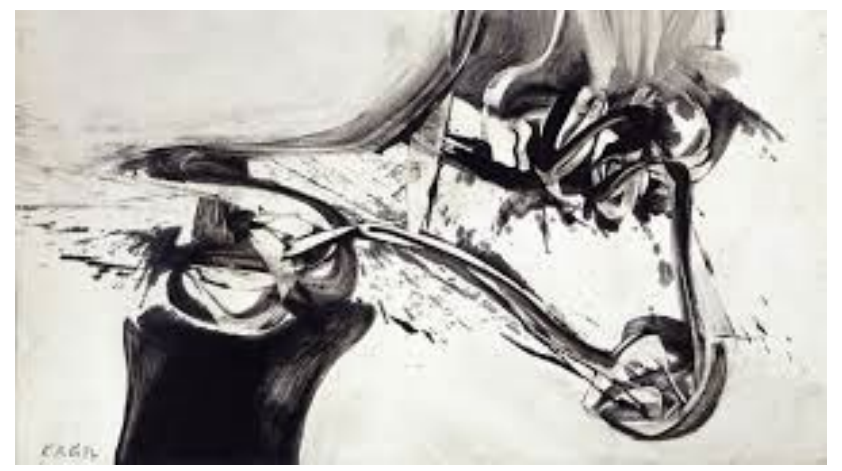

Figure 13 | K.O. Götz, Trefang, 1963.

This became the title of one of his books. Its first edition (of 2,000 copies) was a collection of carefully done silkscreen prints whose production Albers himself controlled.

He painted hundreds of homages to the square. When, in an exhibition, you see a large number of them, you are surprised, if not overwhelmed, by the fantastic differences that those simple variations create in your mind, in your reactions, and emotion. This is so even if you tell yourself that you could easily sit down and, within almost no time, write a program that will generate all of them. In less than one hour you will implement an extremely simple algorithm. For the form (those four nested squares in their constant proportions) is trivial. All the algorithm has to do is: (i) decide whether one of the four squares is to be dropped, and if so, which one; (ii) randomly choose a set of four out of a discrete set of colors. Your "Homage to Albers' Homage to the Square" would run this algorithm, and you could be pretty sure that it takes years before the results would start to repeat.

An interesting detail of Albers' art-turned-research is that, besides giving up all form issues, he very often named - on the back of the carrier material of his paintings (masonite in the majority of cases) - the industrially produced paints he had used. That's pure programming. For he had given up mixing paints and used them as he bought them in tubes.

In 1968, when Albers was still alive, the Zagreb (Croatia) group of artists and theoreticians who had started the "New Tendencies" movement in 1961, continued into the fourth version of that event (in August 1968) by giving it the title "Tendencies 4 . Computers and visual research". I do not know whether this was in direct reference to Josef Albers. If the Zagreb organizers did not decide on this as an explicit reference to Albers' experimental art, implicitly it was so. Does it come as a surprise to anyone that, towards the end of the year 1968, the event of "Nine evenings" was staged in New York, out of which the movement of "Experiments in Art and Technology" (E.A.T.) emerged? In 2018, this celebrated its fiftieth anniversary.

In his reduction to minimal principles (in form), Josef Albers opened up for an explosion of varying color. $\mathrm{He}$ created a situation for precisely controlled experiments. He himself conducted those experiments by hand. As he was doing so, others got ready to describe algorithmically what he was doing manually in an old-fashioned way.

\section{6 | K.O. GÖTZ AND TWO SOULS IN THE CHEST}

The German abstract expressionist painter, Karl Otto Götz (Figure 14), only known as "K.O.", was in some way akin to Pollock, but in some other ways totally different. The two were akin as they both painted out of the movements of their bodies. But Götz did this not, or not only, as a spontaneous action as Pollock may for some short time have done. Götz meditated in preparation of his bodymovements by which he wanted to generate forms that he often sketched ahead of time. When he felt that his thoughts were exactly the movement he needed to do, he jumped up from the chair, literally exploding, picking up paint with a large brush from the nearby container, rushed through the meditated action that his arms and legs were now executing, and was more or less finished. "Images of seconds" (Sekundenbilder), he called them (Figure 13). For seconds, his mind's intention and his body's motion were one and the same, and within those seconds, the painting was finished. It had to be spread out on the floor, as in Pollock's case. But the preparation and action were totally different.

Götz produced a huge work during his long life, a work that testifies techniques as far away from the cool rational thinking needed for algorithmic art as it could ever be. But Götz considered himself as a scientist, too. Not as huge in numbers as his expressive images of seconds, but also remarkable in size and number are his grid images (Rasterbilder, Figure 15). The cells of a large regular grid of small squares are to be filled by color, or left blank. For this, the image format was divided into fields, and each field got associated with a relation of color to blank as, e.g., 60 to 40 . That would mean, 


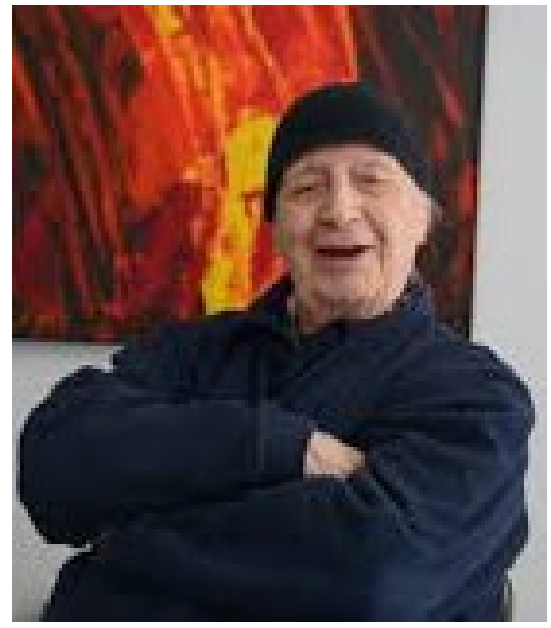

Figure 14 | K.O. Götz (1914-2017).

$60 \%$ of the cells were to be colored, $40 \%$ left uncolored.

Students did the actual diligent coloring, usually with felt pens. Given the ratio of fill to don't fill, the student responsible for one of the fields had to decide for each of the cells in his or her field, what to do. This decision had to obey the given ratio. Students did this by using telephone numbers.

In his grid images, Götz pursuit certain statements and experimental studies inspired by Shannon's information theory. An enormous tension is in the difference of these two parts of Götz's work, a tension between a controlled explosion of the body extended by a long large brush, and a cool planning of experiments that, as in part of Sol LeWitt's work, depends on the availability and readiness of a group of other humans to diligently carry out.

In 1966, shortly after first reports became known about computers being essential in the genera $\neg$ tion of certain simple classes of pictures, K.O. Götz became interested in computers. He himself did not go as far as engaging in algorithmic pictures. But he must have seen a potential for that other part of his work. A potential, perhaps, to rationalize part of the grid filling technique.

Exactly this happened in some of the earliest algorithmic drawings. Predictably, the grid in various forms became a favorite method for some of those early experimentalists. Regular and irregular, static and dynamic grids can easily be applied by use of computers. Each irregular grid is nothing but a transformation of the totally homogeneous grid. Such an approach demonstrates the power of the implemented algorithmic way of thinking.

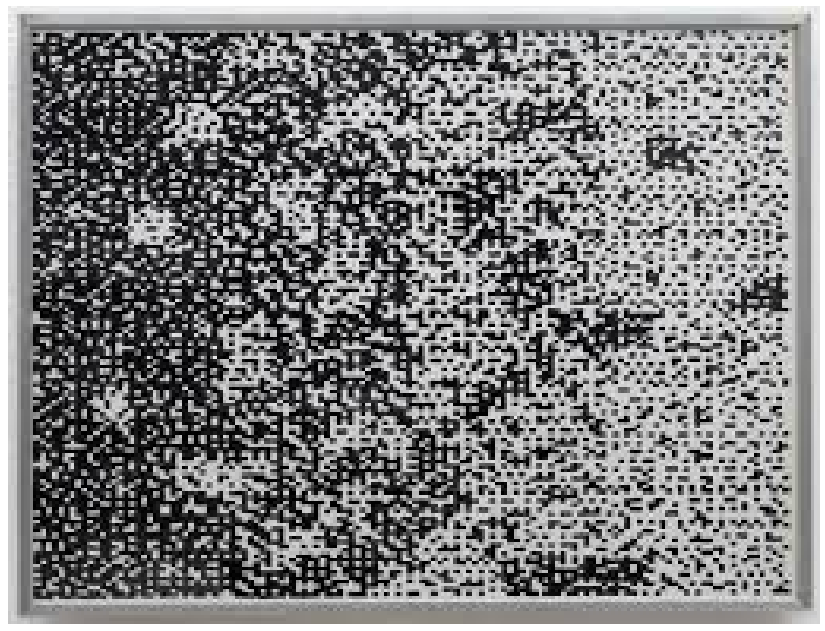

Figure 15 | K.O. Götz, Statistisch-metrisches Rasterbild, 1960.

\section{7 | KURT KRANZ AND INFINITY}

Die Programmierung des Schönen (Programming the Beautiful), was the title of an exhibition in memory of Kurt Kranz (Figure 17), an artist who had studied at Bauhaus during the last few years of its existence (1930-1933, in Berlin), and who later became a professor at the Hochschule für Bildende Künste in Hamburg (1950-1972).

Kurt Kranz worked in series and variations. The endless game of change, and processes of transformation in series of images caught his interest more than the individual painting. Eventually, series became his exclusive mode of expression. An exhibition at Kunsthalle Hamburg in 1990, celebrating his eightieth birthday, was tellingly called The infinite image. In her review of the show, Petra Kipphoff wrote in the German weekly newspaper, DIE ZEIT: "Never was he aiming for the individual image; there never was for him a final form, only the experimental series of form, never a masterpiece, only variants" (our translation; Figure 16).

By that time, algorithmic art was already 25 years old and well established. But what Kranz was searching for and what he expressed, belonged to the starting points and important lessons of generative art: The individual work, the static piece on the wall was hardly of any interest anymore; it got replaced by the class of works the program stands for - always already infinities. We may conclude that, in consequence, there cannot be masterpieces any more. The form of existence of the work is of a double appearance - perceivable by humans, and computable by machines. 


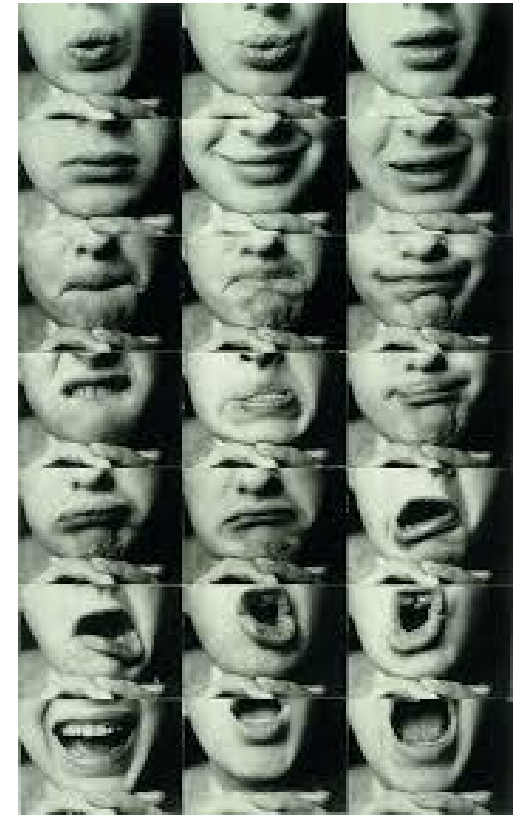

Figure 16 | Kurt Kranz, bacteriasnomeio, 1930s.

Hannes Meyer, the last director of Bauhaus during its Berlin period, had announced that he would work towards connecting three forms of human activity: (i) workshop practice with (ii) free art creation and (iii) scientific research. He was proposing a fruitful cooperation between those three fields of human cultural activities that had developed into different directions. For the Marxist Meyer, as for many innocent practitioners even today, this was a fundamentally wrong development. As a member of Bauhaus, Meyer formulated his position as a critique of the early Weimar phase of Bauhaus (1919-1925). Even more than the founder, Walter Gropius, Meyer emphasized a strict functionalism serving the masses of people instead of serving the needs of the few wealthy and rich living their lives of luxury.

Following Petra Kipphoff's review mentioned above, Kurt Kranz learned from Josef Albers who was teaching the introductory course (Vorkurs) at Bauhaus, that creative and scientific work did not exclude each other, and that art could be carried out as a research activity. Many of us would join in and welcome such a position. It essentially claims that research, the rational and enlightened approach to the world, is not as such alien to the creative artist. But this is exactly what many are propagating nowadays for their actual work. However, we are now more than eighty years later. Has much changed? And if we rightfully notice and claim to see change, how does it actually show up?

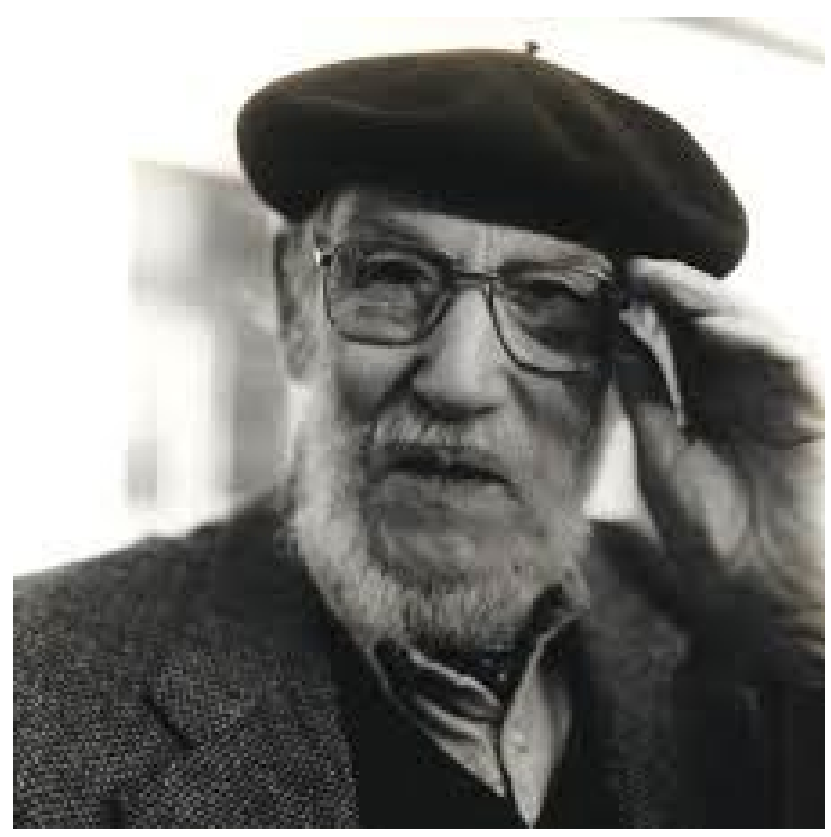

Figure 17 | Kurt Kranz (1910-1997).

If this is so, we should ask ourselves why there is still no unification in sight of art and science happily collaborating. We do read a lot about similar goals and approaches, and about fruitful cases of cooperation. But yet the marvelous journal Leonardo, despite its many efforts in bringing together artists and scientists in joint adventures, has not really torn down walls. Only occasional odd projects may correctly be classified as requiring cooperative or transdisciplinary efforts. Usually in such cases, a small number of dedicated research-scientists struggle hard to generate results of creative works that are accepted as valid results in both of those worlds.

The question may be, after all: Is truth and the search for it - the scientific goal and method - not fundamentally different from beauty and interpretation of its claims, the artistic goal and method?

We may also ask what is different now with the basic infrastructure of, at least, Western-style societies that did not exist in the 1930s of Kurt Kranz and Bauhaus? To give an answer to this question, and a number of related ones, I know of nothing better than to point at the one technology that did then not exist at all, but that is now ubiquitous both in breadth and depth of its distribution. I mean, and everyone will share this with me: computing technology in all its variants. With only a tiny bit of exaggeration, we can say that today nearly everybody is roaming his or her city or village, home or workplace, morning or 
evening, as individual or social activity - always already equipped with a computing machine of small and handy size, of enormous local and global power, and appearing as possessing tool-like and medial qualities at the same time. Computing technology, the semiotic machine, as Mihai Nadin called it (2007), is with us and upon us and underneath everything we do.

What is different, we may say, is that the deepest and most widespread cultural revolution of all times has taken place and is still conquering the seemingly last refuges, and discovering huge new areas of life, still to be turned upside-down such that the young generations rejoice, and the old ones mourn. This permanent revolution must correctly be called "The Algorithmic Revolution": The revolution of transforming into machinic computable form everything that is already computable, and of reducing to computable form everything that is not yet computable. This enormous epochal task has started its path through cultures soon after the founding scientists had come up with their groundbreaking results: Kurt Gödel (1931), Alan M. Turing (1937), and John von Neumann (1945). More and new works are still under way for the algorithmic revolution to creep into all the arteries of human individual and social life. In fact, it is on its way at an accelerating speed, and with an enormous impact. Much of it is devastation.

\section{8| THE MASTERPIECE AND DISAPPEARANCE}

History is not a neatly lined up chain of events, one after or before the other. History does, in the collective memory of a nation or society or humankind, happen when it gets written. Therefore, it is happening all over again, when a new interpretation appears. History is more like a complex graph (if we want to take to such formal language).

In the fine arts, masterpieces appear seldom during the lifetime of their creator. It does happen, occasionally. But the recognition of a painting as being greater in its style or subject than all the others, is usually acknowledged only after the world has had opportunities to formulate such statement.

But now, in times of things and processes being in a permanent state of change, the masterpiece seems to be disappearing. As if it has had its time. "All that is solid melts into air", wrote Marx and Engels in their analysis of bourgeois society (2004). They were pointing at the necessity in capitalism to turn all that into commodity and, thus, into objects of the marketplace, that people would like to keep and hold and be assured of even in the future.

Computers and computing play an enormously important role in this process of melting down everything that used to be fixed and stable. In our field of concern - fine art - we must observe that all things and processes now have a tendency of duplicating. The melting is not a disappearance. It is rather a change of ontological state. Things duplicate into their surface and their subface, when they fall under the change that is called digitization. Under its regime, the surfaces of things and processes, that we are so familiar with, grow a second layer of their ontology. That layer is hidden in the machines, systems, and media of computing. I call it the subface. The subface is real and has great impact. But it is hidden, and we are usually not aware of it. It is hidden in computing equipment, in the cloud. It is computable by the machine, whereas the surface is perceivable by us via our senses. The computable, however decides whether we get credit from the bank. Or whether we are considered to be a potential terrorist. In the case of art, it decides what a work of art (that is no longer static) is going to do and look like in the next moment.

The disappearance of the masterpiece is thus built into the ontology of the works of art. As we become aware of something that we had not observed yet, but now compare and realize that our own idea has already been used elsewhere by someone we have never heard of, we realize that mental priority is disappearing. Everything gets more and more into flux, and the algorithmic revolution is washing away all fundamentals of the bourgeois individual. We used to be surprised by detecting someone before us having done what we have just discovered for ourselves. We must now realize that this is becoming the permanent fate of our cherished capability of creating the new. The new is slowly disappearing, and the old may become the new.

At the crossroads, we see the infinite works that, for artists like Kurt Kranz, were essential for their art. For the algorists, the infinite work is what they always create. Nothing special. 


\section{REFERENCES}

Albers, Josef (1963). Interaction of color. Yale University Press. First as silkscreen edition; as paperback in 1971; expanded fiftieth anniversary edition, 2013.

Gödel, Kurt (1931). Über formal unentscheidbare Sätze der Principia Mathematica und verwandter Systeme, I. Monatshefte für Mathematik und Physik 38, 173-98.

Holloway, John H. \& Well, John A. (1970). A conversation with Josef Albers. Leonardo 3, 459-464

Klüver, Billy \& Martin, Julie (2003). E.A.T. The story of Experiments in Art and Technology 1960-2001. Tokyo : NTT InterCommunication Center.

de La Mettrie, Julien Offray (1912). Man a machine. Chicago: The Open Court Publishing Co. Engl. transl. of the French original of 1748

LeWitt, Sol (1967). Paragraphs on conceptual art. Art Forum 5 no. 10 (June), 79-83.

Marx, Karl \& Engels, Frederick (2004). Manifesto of the communist party. Marxists Internet Archive. Frst published in 1848.

Nadin, Mihai (2007) Semiotic Machine. The Public Journal of Semiotics vol. 1, no. 1, 85-114. von Neumann, John (1945). First draft of a report on the EDVAC.

Turing, Alan M. (1937). On computable numbers with an application to the Entscheidungsproblem. Proceedings of the London Mathematical Society. 2, vol. 42, 230-65.

\section{BIOGRAPHICAL INFORMATION}

Frieder Nake is first a mathematician who did a Ph.D. in probability theory. However, he had moved into computer graphics in 1963, and from there had no choice but to start (independent of A. Michael Noll and Georg Nees) into computer art. In 1965, all three of them had their first exhibitions. He has taught in Stuttgart, Toronto, Vancouver, and Bremen (where he is still living) and many other places around the world. He has published intensively and has supervised hundreds of theses. For the last twenty years, his teaching, lecturing, and publishing has been mainly on topics of art, media, and semiotics. $\mathrm{He}$ is also regularly exhibiting internationally his own works and is represented in a number of museums. 